\title{
RANCANG BANGUN APLIKASI KAMUS BESEMAH BERBASIS APLIKASI ANDROID UNTUK MEMUDAHKAN BELAJAR BAHASA BESEMAH DALAM MELESTARIKAN KEBUDAYAAN BESEMAH KOTA PAGAR ALAM
}

\author{
Ferry Putrawansyah ${ }^{1)}$ dan Siti Aminah ${ }^{2)}$ \\ ${ }^{1,2}$ Program Studi Teknik Informatika, STT Pagar Alam \\ 1,2,Jl. Masik Siagim No,74 Kelurahan Karan Dalo Kecamatan Dempo Tengah, Pagar Alam \\ E-mail : feyputrawansyah@gmail.com ${ }^{1)}$, sitiaminah@gmail.com²
}

\begin{abstract}
ABSTRAK
Penelitian ini bertujuan untuk menghasilkan aplikasi kamus Besemah yang dapat digunakan pada sistem smartphone bersistem operasi Android dengan tujuan untuk digitalisasi kamus Besemah yang saat ini masih konvensional (berupa buku kamus biasa) ke Aplikasi kamus Besemah yang dapat digunakan pada smartphone berbasis sistem operasi android. Penelitian ini di latar belakang oleh mulai hilangnya bahasa asli Besemah yang digunakan dalam komunikasi sehari-hari hal ini karena banyaknya budaya lain yang masuk ke daerah Besemah dan juga kurangnya sarana serta prasarana seperti kamus bahasa besemah atau buku Besemah yang semakin lama semakin sulit didapatkan baik di perpustakaan daerah maupun di toko buku sekitar kota Pagar Alam padahal banyak user (masyarakat Besemah ataupun wisatawan yang datang ke kota Pagar Alam ) yang mencari pustaka untuk dijadikan sebagai media belajar bahasa Besemah untuk berkomunikasi, sehingga dibutuhkan aplikasi yang memudahkan mencari sumber pustaka tersebut. Aplikasi ini dibangun dengan menggunakan bahasa pemrograman java. Metode pengembangan sistem yang digunakan dalam penelitian ini yaitu metode Rapid, Application, Development $(R A D)$.Hasil penelitian menggunakan metode ini yakni expert review menunjukkan nilai rata-rata 4,27 dengan kategori sangat valid. Kemudian berdasarkan hasil kuesioner yang dilakukan kepada user menunjukkan nilai rata-rata 4,3 dengan kategori sangat valid atau sangat aktif sehingga aplikasi kamus Besemah ini dapat diimplementasikan dan juga aplikasi ini dapat mengakomodir user untuk belajar bahasa Besemah sesuai kebutuhan setiap pemakai sebagai pengganti kamus berbentuk konvensional yang efektif dan efisien
\end{abstract}

Kata Kunci: Kamus Besemah, Smartphone, Android, RAD

\section{PENDAHULUAN}

Keberagaman bahasa merupakan salah satu daya tarik bagi wisatawan untuk mengunjungi salah satu daerah di Indonesia untuk sekadar berkomunikasi hingga belajar bahasa tersebut sehingga masyarakat daerah harus dapat melestarikan dan mempertahankan bahasa asli daerah tersebut yang menjadi identitas daerah di tengah masuknya kebudayaan (bahasa) daerah lain.

Melestarikan budaya di era perkembangan teknologi merupakan tantangan yang sangat berat karena dengan mudahnya kebudayaan asing dapat mempengaruhi kebudayaan daerah sehingga kita dituntut untuk dapat mengembangkan berbagai sumber bacaan maupun literatur sebagai media belajar bagi masyarakat daerah tersebut maupun wisatawan asing berbasis layanan teknologi digital.

Kebutuhan masyarakat terhadap layanan teknologi melalui smartphone bersistem operasi android sangat bervariasi, salah satunya adalah kebutuhan akan pembelajaran untuk meningkatkan aspek kognitif, afektif dan psiomotorik. Sarana belajar yang dimaksud dapat berupa multimedia interaktif digital book, sampai ke digital dictionary (kamus digital). Kamus dapat digunakan untuk belajar menggunakan kosakata sampai ke bahasa. Misalnya Kamus bahasa daerah maka kamus menjadi sangat penting mengingat banyak bahasa asli daerah yang mulai hilang karena bahasa lain. Kamus bahasa daerah merupakan salah satu kamus yang di perlukan oleh masyarakat untuk berbagai kepentingan mulai dari promosi daerah, pelestarian budaya sampai ke pembelajaran. (Citra Puji Lestari dkk, 2016)

Perkembangan Smartphone/android telah memberikan banyak manfaat bagi perkembangan teknologi dan manusia. Smartphone merupakan telepon seluler yang menyediakan fitur kompleks yang digitalisasi dokumen konvensional yang mudah diakses dimana pun. Fitur dan kecanggihan pada telepon seluler mulai bermunculan dengan hadirnya berbagai smartphone yang semakin berkembang dimulai dari sistem operasi versi 1.0 sampai versi 10 .

Android bisa dikatakan jawaban dari keragaman masyarakat perkotaan, mengingat mereka mempunyai berbagai kebutuhan pekerjaan yang harus dilakukan dalam waktu bersamaan Menurut (Triady, 2014) Berkat fitur nya yang selalu update, tak heran keberadaan Android mencuri perhatian para penggunanya. Oleh sebab itulah pertumbuhan Android dari tahun ke tahun dapat terlihat secara signifikan. Android adalah sistem operasi (os) bersifat open source (terbuka) yang dimiliki oleh Google Inc. Android dapat digunakan untuk perangkat mobile yaitu telepon seluler sampai dalam komputer tablet. Dari perkembangan sistem operasi Android ini 
yang menjadi sangat populer karena bersifat open source menjadikannya sebagai sistem operasi yang banyak diminati oleh banyak penggunanya. Kelebihan dari Android yakni Complete Platform (CP) Sistem operasi Android merupakan sebuah sistem operasi yang aman dan banyak menyediakan tools dalam membangun software dan memungkinkan untuk peluang pengembangan aplikasi, Open Source Platform (OSP): Platform Android yang bersifat terbuka atau open source menjadikan sistem operasi ini mudah dikembangkan oleh para developer karena bersifat terbuka, Free Platform (FP): Para pengembang atau developer, bebas bisa mengembangkan, mendistribusikan serta memperdagangkan sistem operasi Android tanpa harus membayar loyalty untuk mendapatkan license.

Kelebihan tersebut harus digunakan dengan penggunaan teknologi yang tepat guna seperti kamus digital akan tetapi kamus bahasa daerah yang saat ini beredar masih berbentuk buku sehingga banyak menyulitkan penggunanya ketika harus mencari arti dari sebuah kata sehingga membutuhkan waktu yang cukup lama, di sisi lain buku juga sangat sulit dibawa karena sifatnya yang kurang fleksibel (beda dengan kamus digital). Oleh karena itu dibutuhkan ketersediaan kamus bahasa yang dapat memudahkan semua orang mencari dan memahami arti kata dengan mudah dan cepat dimana pun kita berada. Dengan menggunakan layanan smartphone (Android) sehingga kamus yang berupa digital tentunya akan sangat membantu pengguna (Safaat, 2014)

Kamus merupakan alat bantu yang digunakan untuk menerjemahkan suatu bahasa. Penggunaan kamus sangat diperlukan namun tidak mempersulit pengguna saat menggunakannya dan dapat mempermudah pemakai dalam menerjemahkan suatu bahasa tanpa harus membawa kamus yang berbentuk buku yang memiliki ketebalan dan bobot yang cukup berat untuk ukuran sebuah buku. Untuk itu dibutuhkan sebuah aplikasi yang dapat mengakomodir kebutuhan setiap pemakai sebagai pengganti buku, yang mudah dibawa serta dapat digunakan kapan dan dimana pun secara efektif. Hal tersebut berupa kamus berbasis Android yang dibuat dengan menggunakan bahasa java dan dapat dipasang pada perangkat mobile seperti smartphone.

Menurut penelitian (Suktriayu, 2017) dengan judul "Aplikasi bahasa Paser-Indonesia berbasis Android" dengan hasil aplikasinya dapat pencarian kata lebih cepat dibandingkan mencari secara manual sehingga memudahkan penggunanya dan kamus ini dapat dijadikan media alternatif bagi masyarakat yang ingin mempelajari serta melestarikan bahasa suku Peser dengan memanfaatkan teknologi smartphone berbasis Android kemudian penelitian yang akan dibuat pada aplikasi kamus Besemah berbasis Android akan bertujuan untuk efisien serta melestarikan bahasa Besemah.

Saat ini banyak pengguna yang telah memiliki smartphone sehingga memungkinkan dikembangkan kamus besemah berbasis android yang dapat mempermudah pemakai dalam menerjemahkan suatu bahasa tanpa harus membawa kamus yang berbentuk buku sehingga aplikasi ini dapat membantu semua kebutuhan pembelajaran setiap pemakai sebagai pengganti buku karena sifatnya yang flexible atau mudah dibawa serta dapat digunakan kapan dan dimana pun secara efektif. (Triady, 2014)

Berdasarkan observasi dan wawancara pada Dinas Pendidikan dan Kebudayaan Kota Pagar Alam dengan hasil kurangnya sarana serta prasarana seperti kamus dan buku Besemah yang sulit di dapatkan di toko buku sekitar kota Pagar Alam sebagai alat belajar bahasa Besemah kemudian pencampuran bahasa Besemah dengan bahasa yang lain, hal tersebut dapat menjadikan hilangnya bahasa asli Besemah yang disebabkan karena banyaknya transmigrasi penduduk yang datang dan menetap di kota Pagar Alam oleh karena itu dikhawatirkan bahasa Besemah akan punah. Di sini peneliti juga melakukan observasi dan wawancara pada Dinas Pariwisata Kota Pagar Alam dengan hasil banyaknya wisatawan dan Arkeolog lokal maupun mancanegara yang datang kota Pagar Alam baik berwisata budaya maupun melakukan penelitian yang tertarik untuk mempelajari bahasa Besemah akan tetapi sulitnya mencari buku maupun kamus Besemah sebagai media belajar dan hal itu dapat menimbulkan hilangnya objek wisata budaya yang dimiliki kota Pagar Alam yaitu budaya bahasa Besemah.

Merujuk pada penelitian dengan judul "Aplikasi bahasa Paser-Indonesia berbasis Android" dengan hasil aplikasinya dapat pencarian kata lebih cepat dibandingkan mencari secara manual sehingga memudahkan penggunanya dan kamus ini dapat dijadikan media alternatif bagi masyarakat yang ingin mempelajari serta melestarikan bahasa suku Peser dengan memanfaatkan teknologi smartphone berbasis Android kemudian penelitian yang akan dibuat pada aplikasi kamus Besemah berbasis Android akan bertujuan untuk efisiensi serta melestarikan bahasa Besemah. (Risna Euis Suktriayu, dkk, 2017) kemudian Menurut penelitian (Abidin, 2015) dengan judul "Aplikasi Pencarian kata dalam bahasa Sunda berbasis Android" dengan hasil pengguna terbantu dalam proses belajar bahasa Sunda dengan menggunakan aplikasi ini dan aplikasi pencarian kata dalam bahasa Sunda berbasis Android ini berhasil di jalankan pada smartphone yang berbasis Android, kemudian penelitian yang akan dibuat pada aplikasi kamus Besemah berbasis Android bertujuan mempermudah pengguna dalam proses belajar bahasa Besemah.

Berdasarkan pembahasan diatas disimpulkan bahwa sangat dibutuhkan kehadiran aplikasi kamus bahasa daerah berbasis Android melalui media smartphone yang sangat bermanfaat baik segi efisiensi dalam mencari kata yang ingin di terjemahkan serta dapat membantu melestarikan bahasa daerah tersebut. Kemudian dengan hadirnya aplikasi ini sangat membantu penggunanya dalam proses belajar bahasa daerah. Kamus ini akan membuat тепи terjemahan Indonesia-Besemah, Besemah-Indonesia dan aplikasi kamus Besemah berisikan 2000 kata Besemah. 


\section{RUANG LINGKUP}

Dalam penelitian ini permasalahan mencakup:

1. Penelitian ini membangun aplikasi Kamus Bahasa daerah Besemah menggunakan aplikasi Eclipse Juno dengan database SQLite

2. Metode yang digunakan adalah Rapid, Application Development sementara untuk menguji validitas produk menggunakan uji Alpha

3. Studi kasus yang digunakan khusus untuk Suku Basemah

\section{BAHAN DAN METODE}

Metode pengembangan sistem yang digunakan adalah Rapid Application Development (RAD) yaitu suatu strategi siklus hidup yang ditujukan untuk menyediakan pengembangan yang jauh lebih cepat dan mendapatkan hasil dengan kualitas lebih baik dibandingkan dengan hasil yang dicapai melalui siklus tradisional, Rapid Application Development $(R A D)$ adalah suatu pendekatan berorientasi objek terhadap pengembangan sistem yang mencakup suatu metode pengembangan untuk perangkatperangkat lunak dimana Rapid Application Development $(R A D)$ bertujuan mempersingkat waktu yang biasanya diperlukan dalam siklus hidup pengembangan sistem tradisional antara perancangan dan penerapan suatu sistem informasi. Pada akhirnya, Rapid Application Development (RAD) sama-sama berusaha memenuhi syarat-syarat bisnis yang berubah secara cepat. Kegiatan dengan metode ini merupakan kegiatan yang dilakukan dalam penelitian untuk merancang dan membangun aplikasi kamus Besemah berbasis Android yang valid (Putrawansyah, 2018)

Berdasarkan Kajian teori yang telah di jelaskan maka prosedur dalam penelitian ini akan dilaksanakan dengan menggunakan model pengembangan sistem Rapid Application Development (RAD), metode pengembangan sistem Rapid Application Development (RAD) terdiri dari 3 tahap yaitu requirements planning (perencanaan syaratsyarat), RAD design workshop (workshop desain RAD), dan implementation (implementasi) yang kemudian disesuaikan dengan tujuan dan kondisi penelitian yang sebenarnya. Siklus Metode pengembangan sistem RAD dapat dilihat pada gambar 1 .



\section{Gambar 1. Siklus Rapid Application Development}

Selanjutnya penerapan penelitian yang dilakukan berdasarkan gambar 1, yaitu:

\section{Requirements Planning}

Pada tahap ini analisis kebutuhan dilakukan untuk distribusi produk awal untuk mengetahui kebutuhan yang terkait dengan rencana merancang dan membangun aplikasi kamus Besemah berbasis Android dengan melakukan studi pendahuluan dengan subjek Dinas Pendidikan dan Kebudayaan Kota Pagar Alam dengan menggunakan wawancara.

\section{RAD Design Workshop}

Dalam tahap ini setelah melakukan analisis distribusi produk awal dengan studi pendahuluan yaitu wawancara serta tahap ini juga tahap pengumpulan bahan yang sesuai dengan kebutuhan yang digunakan untuk merancang dan membangun aplikasi kamus Besemah berbasis Android dan Bahan-bahan tersebut antara lain background, content button, scene-scene, picture, serta perancangan yang digunakan dalam membangun aplikasi kamus Besemah berbasis Android yaitu Eclipse dan SQLite

Selanjutnya dalam pembuatan produk aplikasi kamus Besemah berbasis Android ini ada minimum spesifikasi Hardware yang digunakan oleh peneliti antara lain dapat dilihat pada tabel 1 .

Tabel 1. Spesifikasi Hardware Pembuatan Aplikasi

\begin{tabular}{|l|l|}
\hline Nama Perangkat & Spesifikasi Hardware \\
\hline \multirow{4}{*}{ Personal Computer } & $\begin{array}{l}\text { Processor Intel Inside } \\
2.39 \mathrm{GHz}\end{array}$ \\
\cline { 2 - 2 } & Hard Disk 320 GB \\
\cline { 2 - 2 } Smartphone & RAM $2 \mathrm{~GB}$ \\
\cline { 2 - 2 } & VGA 1 GB \\
\hline \multirow{5}{*}{} & Smartphone \\
\cline { 2 - 2 } & Memory 64 GB \\
\cline { 2 - 2 } & RAM 4 GB \\
\hline
\end{tabular}




\section{Implementation}

Tahap ini adalah tahap di mana produk yang dikembangkan sudah jadi dan siap untuk di lakukan testing untuk bisa melihat apakah ada kesalahan atau tidak pada aplikasi kamus Besemah berbasis Android ini. Pengujian yang dilakukan oleh para ahli meliputi ahli aplikasi kamus Android, ahli Bahasa dan ahli Media. Tahap selanjutnya saat produk yang dikembangkan telah selesai melakukan tahap testing (Pengujian) baik pengujian aplikasi kamus, bahasa, serta media yang ada pada produk tersebut selanjutnya produk aplikasi kamus Besemah berbasis Android tersebut siap untuk Diimplementasikan (digunakan) serta di produksi kepada public user. (M.Salahudin, 2016).

\section{PEMBAHASAN}

Setelah Proses Pengumpulan data dan pengumpulan aplikasi pendukung penelitian maka selanjutnya dilakukan pembuatan prosedur penelitian sebagai berikut:

\subsection{Sistem Yang Berjalan}

Sebelum melakukan perancangan terhadap suatu program aplikasi kamus Android terlebih dahulu akan dianalisis kamus Konvensional yang sedang berjalan saat ini. Dimulai dari proses menerjemahkan kata dari bahasa Indonesia/Besemah dan Besemah/Indonesia dengan cara manual yaitu user membuka kamus Besemah konvensional kemudian mencari huruf/kata yang akan di terjemahkan dengan proses membuka buku, mencari sesuai dengan awalan huruf tentunya hal ini akan tidak efektif dan efisien (Edy Wiranto, dkk, 2013)

\subsection{Class Diagram}

Adapun model sistem yang di usulkan oleh peneliti dalam bentuk class diagram yang dijadikan rujukan penulis dalam membuat database pada SQLite dari aplikasi kamus Besemah berbasis Android meliputi Tabel Kamus, tabel terjemahan, tabel kategori, tabel menu utama, bantuan dan tentang yang dapat dilihat pada gambar 2 .

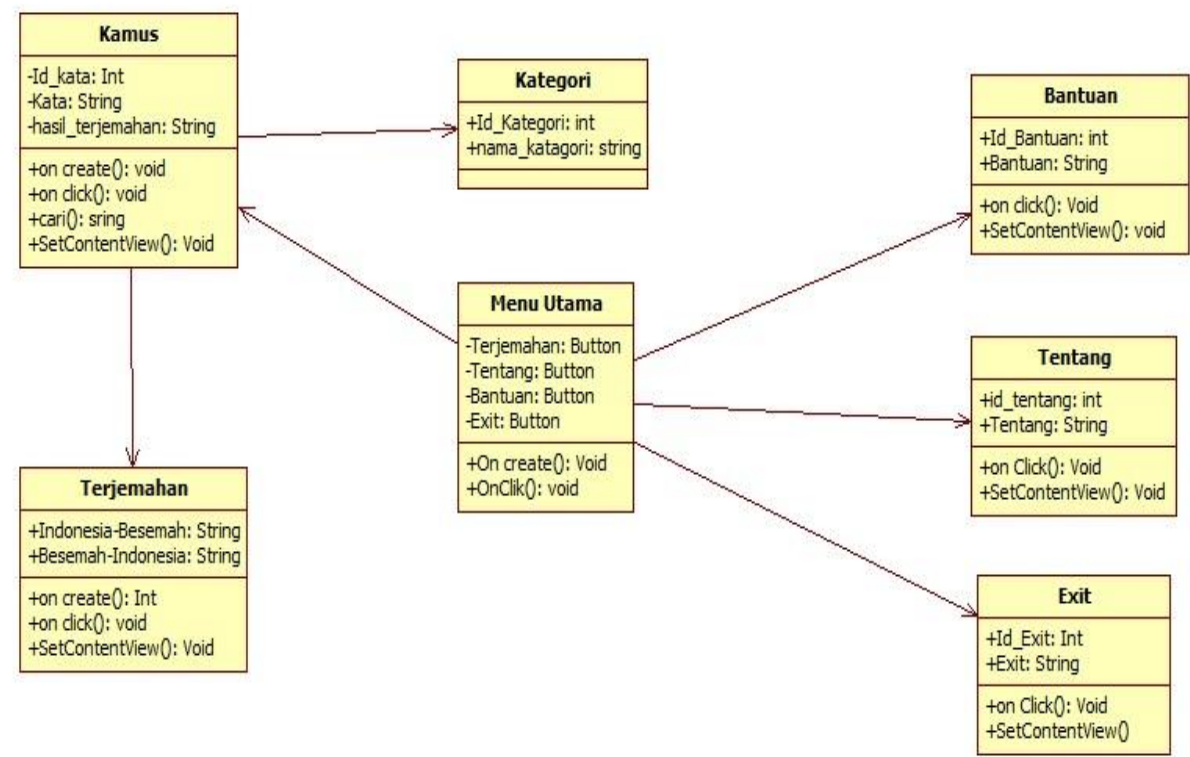

Gambar 2 . Class Diagram

\subsection{Flowchart Sistem Yang Diusulkan}

Sistem yang diusulkan oleh peneliti digambarkan dalam bentuk flowchart yang merupakan pola aplikasi yang akan dibuat meliputi menu dan aliran data saat diakses dimulai pada flow start kemudian akan muncul splash screen, kemudian aplikasi menampilkan 4 menu yaitu terjemahan, tentang, bantuan dan exit. Menu terjemahan akan menampilkan 2 pilihan yaitu terjemahan dari indonesia ke besemah atau dari besemah ke indonesia, menu tentang akan menampilkan informasi tentang kamus besemah, menu bantuan akan menampilkan informasi tentang cara menggunakan aplikasi, kemudian menu exit adalah menu dimana akan keluar dari aplikasi. Adapun flowchart dapat dilihat pada gambar 3. 


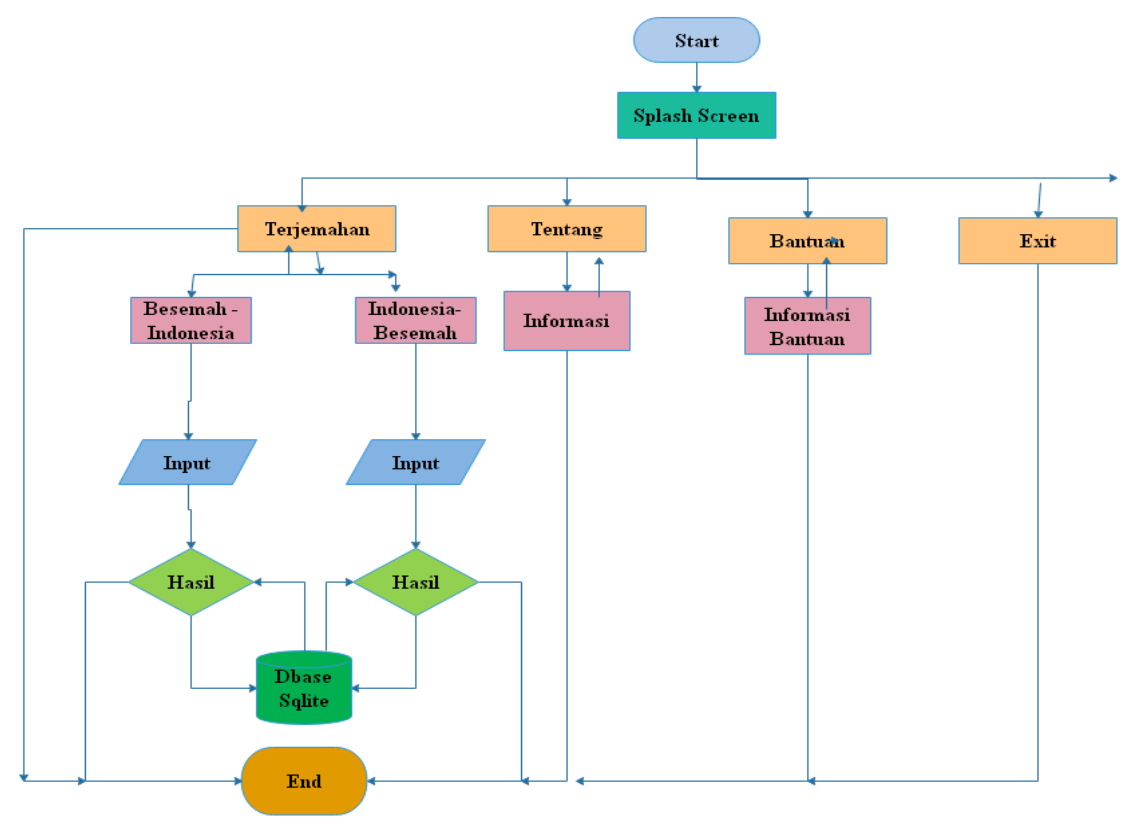

Gambar 3. Desain flowchart Sistem yang diusulkan

4.4 Desain Tabel Terjemahan Indonesia - Besemah

Sistem ini berjalan secara offline, maka tabel yang dibuat pada SQLite dimana Id_bahasa sebagai Primary key pada tabel 2 .

Tabel 2. Database SQLite Indonesia - Besemah

\begin{tabular}{|l|l|l|}
\hline Column Name & $\begin{array}{l}\text { Data } \\
\text { Type }\end{array}$ & Keterangan \\
\hline Id_bahasa* & Int & Id_bahasa \\
\hline Indonesia & Text & Bahasa Indonesia \\
\hline Besemah & Text & Bahasa Besemah \\
\hline
\end{tabular}

*primary key

\subsection{Desain Tabel Informasi}

Tabel 3. ini digunakan untuk memasukan data informasi seperti informasi aplikasi kamus Besemah berbasis Android dan yang menjadi primary key adalah id_Informasi

Tabel 1. Informasi

\begin{tabular}{|l|l|l|}
\hline Name & $\begin{array}{l}\text { Data } \\
\text { Type }\end{array}$ & Keterangan \\
\hline Id_informasi* & Int & Id_informasi \\
\hline Informasi & Text & Informasi \\
\hline Isi & Text & Isi informasi \\
\hline *primary key
\end{tabular}

\subsection{Desain Tabel Bantuan}

Tabel 4. ini digunakan untuk memasukan data bantuan seperti bantuan untuk penggunaan aplikasi kamus Besemah berbasis Android dan yang menjadi primary key adalah $i d \_b a n t u a n$.
Tabel 2. Bantuan

\begin{tabular}{|l|l|l|}
\hline Name & $\begin{array}{l}\text { Data } \\
\text { Type }\end{array}$ & Keterangan \\
\hline Id_bantuan* & Int & Id bantuan \\
\hline Bantuan & Text & Bantuan \\
\hline Isi & Text & Isi bantuan \\
\hline
\end{tabular}

*primary key

\subsection{Hasil Implementasi}

Setelah pembuatan Aplikasi menggunakan Android Studio dan database SQLite maka tampilan hasil dapat dilihat sebagai berikut:

\section{Halaman Menu Ponsel}

Pada menu ini, user menjalankan aplikasi kamus Besemah berbasis Android, dapat memilih atau menyentuh icon aplikasi kamus Besemah berbasis Android. Tampilan Icon dapat dilihat pad gambar 4.

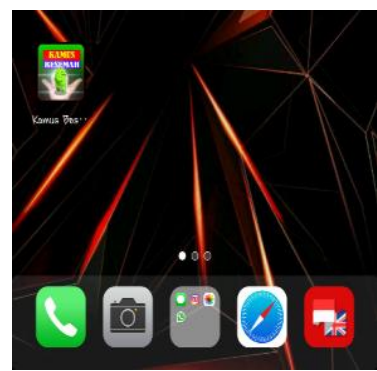

Gambar 4. Halaman Menu Ponsel 


\section{Halaman Splash Screen}

Halaman ini merupakan halaman pembukaan dari aplikasi kamus Besemah berbasis Android dan secara langsung menuju halaman menu selanjutnya yaitu splash screen yang dapat dilihat pada gambar 5 .

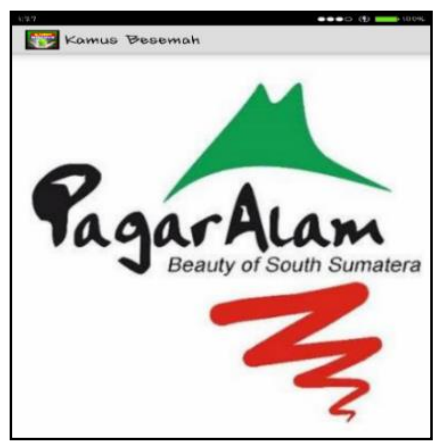

\section{Gambar 5. Tampilan Splash Screen}

\section{Halaman Menu Home}

Halaman ini merupakan halaman menu home dari aplikasi kamus Besemah berbasis Android yang memberikan informasi ada apa saja pada aplikasi kamus Besemah berbasis Android, yang disediakan pada setiap mеnu-тепи index. Pada halaman ini terdapat empat pilihan тепи yaitu terjemahkan, informasi, bantuan dan exit. Berikut tampilan mепи home dapat dilihat pada gambar 6.

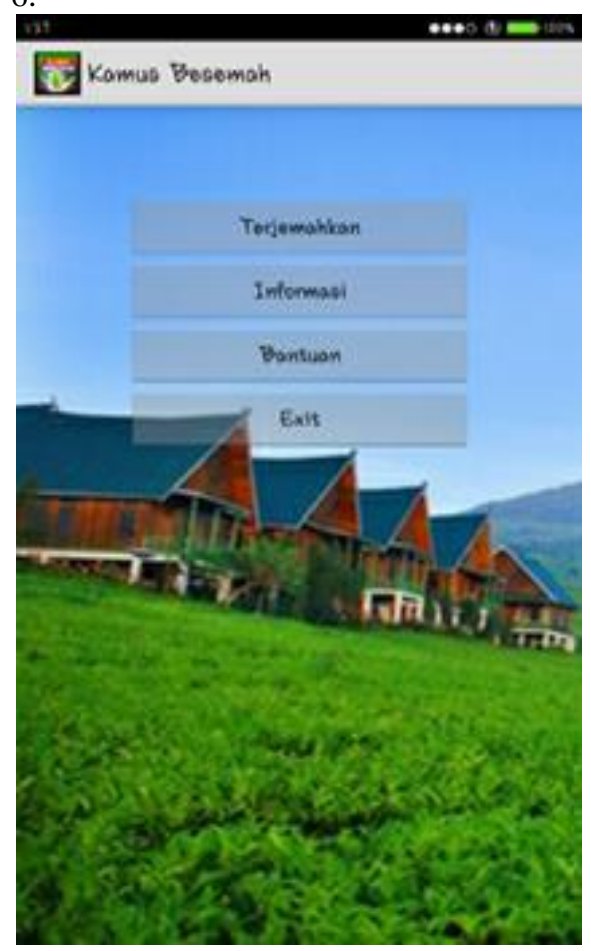

Gambar 6. Halaman Menu Home

4. Halaman Menu Terjemahan

Halaman ini merupakan halaman isi dari menu yang ada pada Menu terjemahan Pada halaman ini terdapat 2 pilihan mеnu terjemahan yaitu Besemah-Indonesia dan
Indonesia-Besemah yang berbentuk radio button. Tampilan dapat dilihat pada gambar 7 .

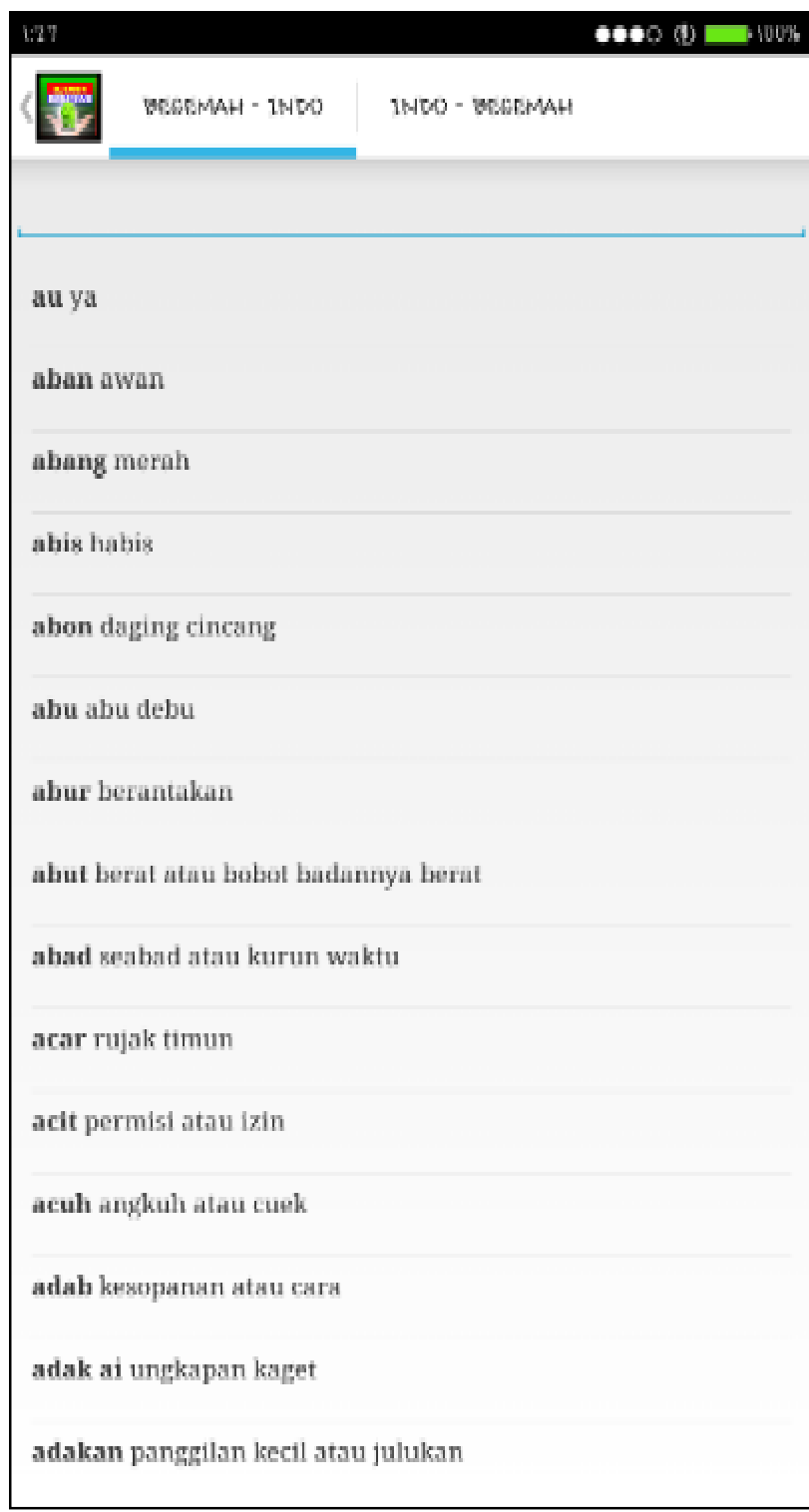

\section{Gambar 7. Halaman Menu Terjemahan}

5. Halaman Arti Terjemahan Kata Indonesia - Besemah Halaman ini merupakan halaman arti terjemahan kata dari bahasa Indonesia ke bahasa Besemah Berikut halaman arti terjemahan dari kata Indonesia - Besemah dapat dilihat pada gambar 8 .

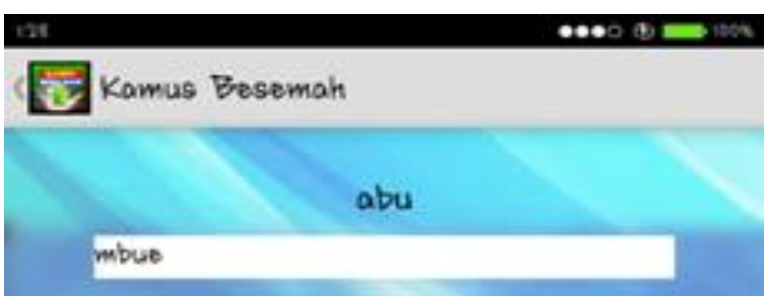

Gambar 8. Arti Terjemahan Kata Indonesia Besemah 
6. Halaman Menu Informasi

Halaman ini merupakan halaman isi dari menu yang ada pada informasi. Pada halaman ini akan dijelaskan Informasi Aplikasi kamus Besemah berbasis Android dan sumber kosakata yang didapat. Tampilannya dapat dilihat pada gambar 9 .

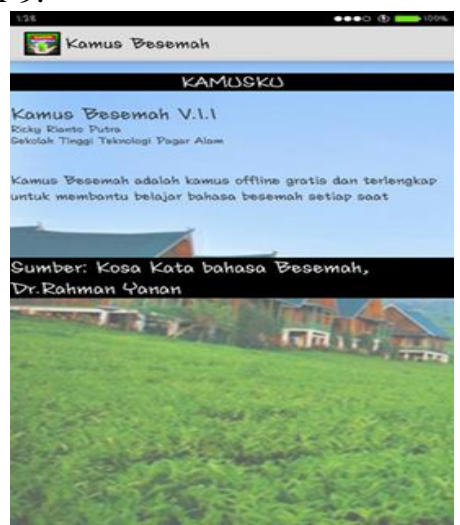

Gambar 9. Halaman Menu Informasi

\section{Halaman Menu Bantuan}

Halaman ini menampilkan petunjuk penggunaan aplikasi kamus Besemah berbasis Android jadi apabila user tidak mengerti bagaimana cara penggunaan aplikasi ini peneliti menyiapkan form atau mеnu bantuan untuk membantu user tersebut. Tampilannya dapat dilihat pada gambar 10

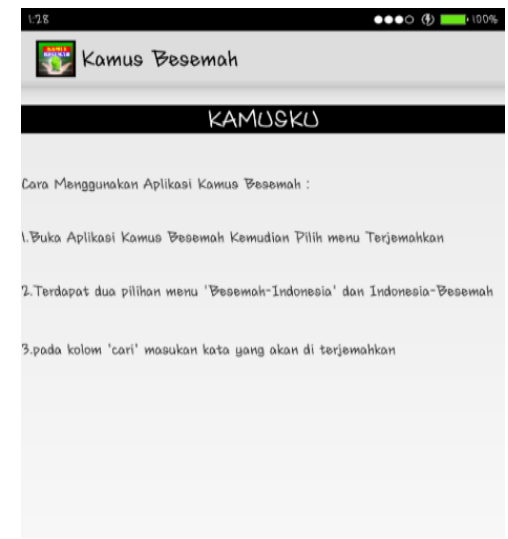

Gambar 10. Halaman Menu Bantuan

\subsection{Pengujian}

Tahap ini di mana produk yang dikembangkan sudah jadi dan dilakukan testing oleh para ahli meliputi ahli media Android, ahli Bahasa dan ahli media desain Android (Yana Setiono, dkk, 2016).

Berdasarkan hasil kuesioner expert review didapatkan hasil pada uji bahasa dan kosakata bahasa Besemah didapatkan skor rata-rata 4,6 dengan kriteria sangat valid, kemudian uji media desain Android pada aplikasi kamus Besemah berbasis Android dengan skor 4 dengan kriteria valid dan uji media Android didapatkan skor 4,2 dengan kriteria sangat valid dengan hasil rata-rata 4,27 dengan kategori sangat valid. Berikut adalah diagram hasil rekapitulasi nilai angket expert review pada gambar 11 .

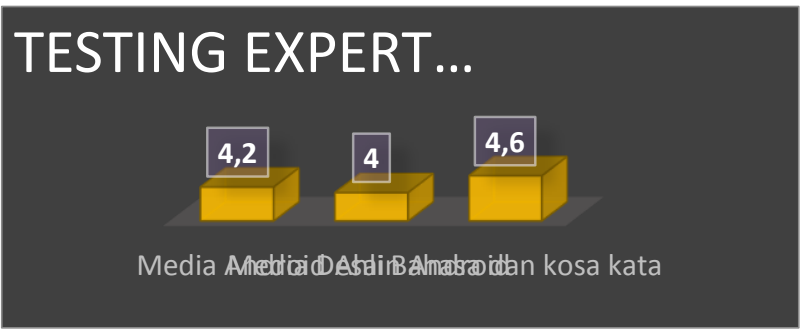

Gambar 11. Grafik Testing Expert Review

Setelah melakukan uji coba expert review untuk mendapatkan produk yang valid maka selanjutnya di lakukan testing kepada 27 user. aplikasi kamus bahasa Besemah berbasis Android diujikan kepada 27 orang mahasiswa tersebut, penulis melihat dan menilai keaktifan user tersebut dengan data yang dikumpulkan berupa angket dan didapatkan skor rata-rata 4,3 dengan kategori sangat valid. Berikut adalah diagram hasil rekapitulasi nilai angket expert review dan testing user:

Setelah produk aplikasi kamus Besemah berbasis Android selesai melalui tahap testing, selanjutnya produk aplikasi kamus Besemah berbasis Android siap untuk diimplementasikan pada public.

\section{KESIMPULAN}

Aplikasi kamus Besemah berbasis Android telah dihasilkan dengan aplikasi ini diakses secara offline, Aplikasi kamus Besemah berbasis Android berisi 2000 kosakata Besemah, Aplikasi kamus Besemah berbasis Android dinyatakan sangat valid. Data diperoleh dari hasil kuesioner expert review didapatkan hasil pada uji bahasa adan kosakata bahasa Besemah didapatkan skor rata-rata 4,6 dengan kriteria sangat valid, kemudian uji media desain Android pada aplikasi kamus Besemah berbasis Android dengan skor 4 dengan kriteria valid dan uji media Android didapatkan skor 4,2 dengan kriteria sangat valid dengan hasil rata-rata 4,27 dengan kategori sangat valid. Dan saat ini aplikasi telah digunakan oleh banyak user untuk belajar dan sudah dibagikan secara bebas di internet.

\section{SARAN}

Saran untuk penelitian berikutnya ditambahkan menu belajar aksara Besemah, Dialog/percakapan Audio dan Video.

\section{DAFTAR PUSTAKA}

Lestari, C. P., Hasibuan, N. A., \& Ginting, G. L. 2016. Perancangan Aplikasi Kamus Istilah Medis Berbasis Android Dengan Algoritma Boyer- Moore. INFOTEK, 28-32. 
M. Salahudin, R. 2016. Rekayasa Perangkat Lunak Terstruktur dan Berorientasi Objek. bandung: Informatika.

Parno, D. N. 2011. Aplikasi Mobile istilah Psikologi Berbasis Android. Proceeding PESAT (Psikologi, Ekonomi, Sastra, Arsitektur dan Sipil) Universitas Guna darma, 121-127.

Putrawansyah, F. 2018. Perancangan \& Implementasi Aplikasi Kamus Teknik Sipil Berbasis Android Dengan Menggunakan Eclipse Juno. Indonesian Journal Of Computer Science, 1-7.

Suktriayu, R. E., dkk. 2017. Aplikasi Kamus Bahasa Paser-Indonesia Berbasis Android. Prosiding Seminar nasional Ilmu Komputer dan Teknologi Informasi, 152-154.

Safaat, N. 2014. Android Pemrograman Aplikasi Mobile Smartphone dan Tablet Pc Berbasis Android. Bandung: INFORMATIKA.

Triady. 2014. Bedah Tuntas Fitur Android. yogyakarta: andi publisher.

Setiono, Y. 2016. pengembangan smart application translation aneka bahasa sulawesi. teknisi, 55-64.

Abidin, Z., Sari, A. P., \& Nasution, R. 2015. Aplikasi Pencarian Kata Dalam Bahasa Sunda Menggunakan Algoritma Boyer Moore Berbasis Android. Konferensi Nasional Ilmu Sosial dan Teknologi, 1(1). 